\title{
Oliveira Martins e o Brasil ${ }^{*}$ \\ Paulo Franchetti
}

$\mathrm{Na}$ história da cultura portuguesa do século XIX, um dos atores coletivos mais importantes é o que se convencionou chamar "Geração de 70". Por esse nome, designa-se um conjunto de intelectuais que são assim reunidos por neles se reconhecer o desejo de proceder a uma campanha de reforma da nação, a partir de ideais republicanos ou socialistas. Reforma essa que se apresenta primeiramente como um esforço de submeter a processo a história do país e da constituição do império ultramarino.

O momento central de constituição pública do grupo, que reflete inclusive no rótulo atribuído à "Geração", foram as Conferências Democráticas, de 1871. Do programa bastante amplo, como se sabe, apenas cinco foram proferidas: a de abertura, a de Antero, sobre as Causas da decadência dos povos peninsulares nos últimos três séculos; a de Augusto Soromenho, sobre A literatura portuguesa; a de Eça, sobre $A$ nova literatura; e a de Adolfo Coelho, sobre $O$ ensino em Portugal. Suspensas por ordem governamental, o que delas restou, além do programa ambicioso e revolucionário, foi a atitude comum que animava os vários textos: promover, pela denúncia do estado atual de estagnação e atraso da cultura portuguesa, os valores modernos, científicos e revolucionários. Nesse sentido, o texto que sintetiza o programa de revisão histórica das Conferências e da "Geração" é mesmo o de Antero de Quental, e não creio que exagere ao dizer que é esse talvez o texto capital da cultura portuguesa no século XIX, pois representa, simultaneamente, um ponto de chegada e um ponto de partida. De chegada porque dá nova síntese, numa clave revolucionária, a temas e questões que já vinham de Herculano. De partida, porque é das teses polêmicas desse texto seminal que nascem, por decorrência ou por contradição, algumas das obras fundamentais para a definição da cultura portuguesa do final do século XIX e começo do XX. 
O texto de Antero desenvolve, de modo brilhante, o que depois se tornou o tema central do tempo: o diagnóstico da decadência portuguesa. Essa é a palavra-chave no pensamento dessa época, e a história das várias modalizações do sentimento de decadência na segunda metade dos oitocentos já foi muito bem feita por António Machado Pires, num livro publicado em $1978 .{ }^{1}$

Dentro do propósito crítico e revolucionário que se reconhece sob a denominação de "Geração de 70" - e necessitando, portanto, desse enquadramento, para ser adequadamente compreendido -, avulta um conjunto de trabalhos que, pelo seu escopo, pela sua grandeza, e pela presença decisiva que teve e ainda tem na cultura luso-brasileira, atrai de imediato a atenção de quem quer que se interesse pelo estudo das coordenadas ideológicas do final do século XIX. Trata-se da obra de Oliveira Martins.

Com o mesmo objetivo com que foram pensadas as Conferências, isto é, com o objetivo de educar o público, de promover a sua atualização como estratégia para reformar a sociedade e reverter a decadência nacional, projetou e compôs Martins uma vasta Biblioteca das Ciências Sociais, em que os volumes se referem mutuamente e cobrem campos muito amplos, da antropologia à crematística, da etnologia à história do sistema colonial português, da história de Roma à crônica do Portugal seu contemporâneo. ${ }^{2}$

No centro desse grande painel, como um eixo sobre o qual giram todas as questões maiores, está uma questão e um país. O país é Portugal; a questão é a decadência e a tentativa de discernir algum caminho possível para revertê-la. A alicerçar o conjunto, fazendo de livros de divulgação (livremente adaptados dos autores mais prestigiosos do tempo) obras que apresentam interesse próprio, está o estilo poderoso de Oliveira Martins, a arte verbal que faz dele, na opinião de António Sérgio, o "mais rico e substancial de todos os prosadores da nossa língua".

É talvez ao estilo, à qualidade artística do texto de Martins que se deve atribuir parte do persistente interesse pelos seus livros em Portugal 
e, principalmente, no Brasil. A História de Portugal lê-se como um romance emocionante, cheio de suspense, de presságios e de lances dramáticos e pitorescos. As suas biografias dos homens de Avis nada ficam a dever, em termos de arte verbal, às boas novelas históricas oitocentistas. Daí que, ainda em 1913, na resposta a um inquérito literário, um intelectual brasileiro, Dantas Barreto, listasse, entre os seus autores preferidos, Oliveira Martins, juntamente com Shakespeare, Goethe, Camões, Alexandre Herculano e Eça de Queirós... ${ }^{4}$ Mas, não creio que seja só o estilo de Martins que responda pela sua permanência no centro do interesse da cultura brasileira do final do século XIX e início do XX. Penso que, além do estilo, interessa ao leitor brasileiro a sua peculiar visão dos rumos da cultura portuguesa e do que foi a colonização do Brasil.

Hoje não são certamente muitos os que, no Brasil, tiveram a oportunidade de conhecer diretamente o texto e as idéias de Martins. Mas essas idéias são ainda parte da cultura brasileira de uma forma muito mais intrínseca do que poderia parecer a uma primeira vista de olhos.

Um episódio recente pode servir aqui de exemplo.

Há sete anos, em 1995 (cento e um anos, portanto, depois da morte de Oliveira Martins), foi publicado um volume reunindo a correspondência entre ele e seu amigo e companheiro de geração, Eça de Queirós. A publicação, de caráter estritamente acadêmico, provocou uma inesperada resenha de Antonio Callado, na Folha de S. Paulo. Inesperada porque poucos dias antes o jornal trouxera uma matéria sobre o livro, e porque a coluna do autor de Quarup pouco se ocupava de assuntos relativos à cultura portuguesa, e menos ainda de temas ou textos acadêmicos.

O notável no texto de Callado era o tom: expunha aí o escritor brasileiro toda a sua calorosa admiração pela prosa de Martins, de que transcrevia várias passagens, pelas quais era evidente o seu fascínio. Mais do que isso, servia a resenha de pretexto para que apresentasse uma confissão de quanto a obra do escritor português tinha marcado sua visão de Portugal e das raízes históricas da civilização brasileira: "talvez eu nunca 
tenha sentido tanto a ligação lusitana como quando li, no meu voluntário exílio em Londres, durante a guerra, a História de Portugal de Oliveira Martins", escreveu ele.

Outro ponto interessante dessa resenha é que nela Callado atribuía à influência de Martins o tom galhofeiro com que, vez por outra, na sua coluna, tinha tratado Portugal, principalmente quando se ocupou de comentar o filme Carlota Joaquina.

Ora, além de nos dar um depoimento eloqüente da persistência, no Brasil, da influência dos livros de Oliveira Martins, esse texto de Callado, ao referir o filme recentemente lançado, aliava ao testemunho pessoal um testemunho cultural, pois Carlota Joaquina era a mais recente atualização artística grandemente tributária da História de Portugal. De fato, quem quer que tenha lido as obras de Martins percebe imediatamente que, apesar do esforço enorme de Oliveira Lima para recuperar, numa clave mais positiva, o papel e a figura de D. João VI, Carlota Joaquina bebe em Martins todos os estereótipos sobre os quais monta a sátira da corte e da balofa figura do monarca e sua mulher ninfomaníaca.

Para alguns intelectuais portugueses que visitam o Brasil, a permanência das obras de Martins no horizonte da cultura brasileira causa sempre algum espanto. Um bom exemplo ocorreu nessa mesma ocasião: o prof. João Medina, que por acaso estava em São Paulo quando Callado publicou a referida resenha, dirigiu-lhe uma longa carta, manifestando seu espanto por Martins ser assim uma referência tão central para o intelectual brasileiro, e aproveitando a ocasião para lhe apresentar o que julgava ser de fato o lugar de Martins na historiografia portuguesa... Pondo de lado o caráter anedótico do episódio, não deixa de ser curiosa essa permanência do historiador português como presença ativa. Afinal, desde 1879, que é o ano da publicação da História, mudaram os paradigmas que regem o discurso histórico e aumentou muito o nosso conhecimento documental sobre as várias épocas retratadas por Martins. Entretanto, basta observar as bibliografias dos programas de literatura portuguesa de várias universidades brasileiras para ver que em muitas ainda constam, 
como textos referenciais, os livros de Oliveira Martins. A que se deverá isso? Como explicar a persistência da visada histórica do escritor português ao longo de um século inteiro?

Reservando sempre o recurso à força do estilo, à evidente qualidade literária de sua obra, há outras razões para que ele tenha sido tão lido e meditado, principalmente no Brasil. Uma delas é que, como se reconhece cada vez mais claramente nos dias de hoje, encontra-se em Martins uma profunda e original interpretação da sociedade portuguesa.

Malgrado o que possa haver de incorreto, de lacunar, do ponto de vista documental, e mesmo de apressado e tendencioso no julgamento dos dados de que dispunha, ainda parece plausível a afirmação de António José Saraiva, "ele entendeu que a realidade se processa de dentro para fora, da semente para a flor, ao passo que os historiadores comuns, julgando-se cientistas, procedem de fora para dentro, como é habitual na análise científica, mas afastando-se cada vez mais daquilo que pretendem explicar [...] É por isso - continua Saraiva - que, em comparação com esta História de Portugal, as outras, à sua luz, nos aparecem como sombras imperfeitas". 5

Por outro lado, em nenhum outro escritor português do século XIX se poderá encontrar uma crítica tão feroz, sistemática e radical do seu país e da sua cultura. Assim, ou porque os nossos escritores reconhecessem a propriedade da intuição martiniana sobre a constituição da sociedade portuguesa, ou porque Martins oferecesse, ao sentimento antilusitano exacerbado no período republicano, farto material de combate e embasamento crítico - ou por essas duas razões combinadas -, foi o escritor português aproveitado muito extensamente por pensadores que, no início do presente século, se dedicaram a refletir sobre o Brasil e sobre o significado, na nossa vida política e social, da herança da colonização portuguesa.

Seja como for, do que não há dúvida é que boa parte da literatura de caráter reflexivo sobre a sociedade brasileira, no final do século XIX e começo do XX, tem como referência importante, a negar ou a afirmar, a 
obra histórica de Oliveira Martins. Suas teses, muitas vezes já desvinculadas de seus textos, formam uma espécie de solo comum de algumas das mais fortes interpretações do sentido da herança portuguesa na formação do Brasil. Dissolvidas, aclamadas ou contestadas, suas idéias parecem ter penetrado profundamente na cultura do país. E é por isso que a leitura de qualquer dos livros de Oliveira Martins provoca ainda hoje em qualquer brasileiro culto, como provocou em Antonio Callado, uma espécie de efeito de reconhecimento: está ali, sistematizado num conjunto coeso, muito do que no Brasil se foi pensando do que foi Portugal na história da civilização ocidental.

Um comentário rápido de alguns textos e documentos da cultura brasileira do final do século XIX e começo do século XX permitirá aquilatar melhor a receptividade que tiveram no Brasil os livros de Oliveira Martins. Antes, porém, já que os seus livros não continuam talvez a ser tão lidos, vale a pena proceder a um resumo das suas idéias centrais sobre Portugal e, principalmente, sobre o Brasil.

A História de Portugal é um livro de cuja leitura, nas palavras de António Sérgio, uma pessoa sai confusa e perturbada, com “ 'cinco impressões essenciais' sobre o país: em primeiro lugar, um sentimento geral de desencanto, de incapacidade, de bolor, desde o século XVI até agora; depois, a ignomínia dos lauréis da Índia; e o nosso ingênito sebastianismo; e a negra educação dos jesuítas; e a série mofina dos reis de Bragança, desde D. João IV a D. João VI”. ${ }^{6}$

É verdade. De um modo geral, a História de Martins é mesmo um panorama triste e pessimista da vida da nação. Mas cheio de cores, de ação e lances romanescos. Forma a sua espinha dorsal, mais do que a narração objetiva dos acontecimentos dispostos em ordem cronológica, uma série de quadros impressivos, dramáticos, mais ou menos trágicos e relativamente completos em si mesmos. Do meu ponto de vista, além das que Sérgio assinalou há uma sexta "impressão essencial": a de que o fio condutor da narrativa é a exposição de uma persistente e equívoca loucura coletiva, que acaba por dirigir o fluxo dos acontecimentos mar- 
cantes na história pátria. Persistente, porque não é privativa de nenhuma das casas reinantes; e equívoca porque, de acordo com o momento, ora parece bastante desprezível, ora puramente trágica, ora sublime.

A maior parte do livro, como já se depreende das impressões de Sérgio, gira à volta do tema da decadência portuguesa. Tudo o que sobreveio depois de 1580 é visto apenas como um longo estertor, em que se debate inutilmente um indivíduo condenado, um demorado e arrastado processo de decomposição de um corpo social já sem vida própria. $\mathrm{E}$ mesmo antes, desde D. Manuel, a narração é cheia de prefigurações da desgraça, de que Alcácer-Quibir é apenas o desenlace formidável.

Outra tese fundamental que organiza a visada martiniana é a de que, inaugurado sem uma base rácica ou geográfica, Portugal se afirma como nação com a dinastia de Avis, quando encontra e realiza a sua vocação marítima.

É no desenvolvimento da vida marítima, ou melhor, na transformação de Portugal de país agrário em país dedicado ao comércio por mar que Oliveira Martins vai radicar a própria sobrevivência da nação portuguesa, garantida pela Revolução de 1383: "Portugal foi Lisboa, e sem Lisboa não teria resistido à força absorvente do movimento de unificação do corpo peninsular", diz ele na sua História, e completa, no Portugal nos Mares: "Portugal é Lisboa, escrevi eu algures. Devia ter dito antes que Lisboa absorveu Portugal, pois esta expressão corresponde melhor à verdade histórica. [...] Desde que a vida marítima e ultramarina nos absorveu de todo, a capital e o seu porto, como um cérebro congestionado, mirraram as províncias. Portugal passou a ser Lisboa: uma cabeça de gigante num corpo de pigmeu".?

Mas justamente nessa frase já se mostra o destino trágico da nação. Formado assim para o mar, sem corpo que sustentasse o desenvolvimento desproporcional da ciência e do comércio marítimo, Portugal duraria enquanto durasse o desígnio que o criou: a exploração e o domínio do oceano. 
É um curto período, esse da pujança da nação. Do ponto de vista de Oliveira Martins não vai além do reinado de D. João II. Já no tempo de D. Manuel, a tônica da sua narrativa é a senectude e a decadência. Tanto é assim que o livro V enfeixa sob o título de "A Catástrofe" os reinados de D. Manuel, D. João III e D. Sebastião. Na verdade, os três podem ser lidos como encarnação da tríade responsável pela decadência portuguesa, conforme fora descrita por Antero, no famoso texto das Conferências Democráticas: D. Manuel é o desfecho da aventura marítima, com a exploração criminosa da Índia; D. João III é o triunfo do catolicismo tridentino, jesuítico e inquisitorial; e D. Sebastião é a loucura, que só se torna realidade social, coletiva, devido ao regime político absolutista e ao fanatismo religioso que o embasava.

Desse ponto de vista, com a catástrofe de África acaba Portugal isto é, acaba aquela primeira nação, no sentido que essa palavra tinha em seu pensamento. Portugal passa a ser, quando muito, uma nacionalidade. ${ }^{8}$ A Restauração de 1640 produzirá um outro ser político, sobre o mesmo território e com o mesmo nome e língua. É o que lemos na Introdução à História, quando o Portugal restaurado é comparado à Bélgica, fruto artificial das necessidades do equilíbrio europeu, e reduzido às proporções de um protetorado inglês encravado na Europa, cujos feitores serão os reis da dinastia de Bragança.

Uma das mais fortes influências de Oliveira Martins se exerceu justamente nessa assimilação da história de Portugal - nascimento, crescimento e morte - à história das dinastias de Borgonha e Avis, relegando para o domínio da farsa insubsistente a narração dos sucessos da época bragantina.

A pergunta que, nesse quadro, se impõe imediatamente é: como se processou a colonização do Brasil? Como foi possível a construção da nova terra portuguesa no mesmo momento em que a metrópole morria, deixava de ser um organismo vivo? O que o Brasil herdou de Portugal e no que o superou ou the ficou inferior? As respostas a essas perguntas, ou a algumas delas, são dadas, por Martins, em outro volume, que se 
intitula O Brasil e as colônias portuguesas e que foi publicado pela primeira vez em 1880.

Para bem compreender as articulações centrais do pensamento de Martins sobre o Brasil, distingamos logo de início algumas questões de fundo. Em primeiro lugar, para o historiador Brasil e África formavam um verdadeiro sistema, em que o lugar determinante era ocupado pelo Brasil. O domínio africano foi, para ele, uma clara função dos interesses colonizadores da América: uma fonte de mão-de-obra, e pouco mais do que isso. A esse sistema de exploração colonial opunha-se na economia portuguesa, com ele coexistindo, um outro: o Império da Índia, que Martins descreve como uma empresa anárquica, baseada na conquista, no saque e no comércio.

Cada um desses sistemas representava um lado do gênio nacional português, uma face de um único ser bifronte. Portanto, não se pode entender perfeitamente a narrativa da colonização do Brasil, segundo Martins, se não tivermos em mente a sua narrativa do Império da Índia. Num caso, o desastre, a tragédia; no outro, o sucesso e a obra imorredoura. Assim, enquanto na Índia tudo eram miragens e iniqüidades, onde "os portugueses davam larga ao seu gênio guerreiro e mercantil; na África e na América obedeciam aos impulsos mais felizes do seu gênio indagador e audaz". Já aqui se detecta o problema principal dessa formulação, que se pode sintetizar nesta pergunta: nos termos da visão martiniana, como a mesma nação, que desaparecerá como tal em 1580, pôde encontrar a energia necessária à grande obra da colonização brasileira?

No quadro conceitual da História de Portugal, o Brasil vai aparecer como uma espécie de persistência possível dos caracteres positivos que o autor atribuía aos homens do período de Avis. Tudo se passa como se, perdido o tônus nacional na metrópole, tivesse sido ele preservado na população portuguesa da América, que, afastada da fonte de corrupção que era a corte, manteve, dirigida para o sertão interior, "a mesma tenacidade com que antes [os portugueses] tinham querido desvendar, e tinham desvendado, os segredos do mar". Era essa tenacidade, essa força 
do gênio lusitano "que os impelia agora a descobrir os segredos desses vastos e espessos sertões da África e da América austrais". Essa idéia recorre em várias partes do livro. Por exemplo, quando trata do Nordeste brasileiro, escreve Martins esta frase, devidamente enfatizada cinqüenta anos depois por Gilberto Freyre: "a população, especialmente no Norte, constituiu-se aristocraticamente: isto é, as casas de Portugal enviaram ramos para o Ultramar, e desde todo o princípio a colônia apresentou um aspecto diverso das turbulentas imigrações dos castelhanos na América Central e Ocidental”. Já quando trata do Sul, descobre sempre nos paulistas as qualidades mais destacadas do período áureo da nação portuguesa: nos habitantes de São Paulo, diz ele, "a semente do gênio descobridor dos portugueses pudera medrar livremente, à sombra de um clima benigno e de uma colonização naturalmente agrícola".

Mas essa semente não germinaria, seria destruída pela atonia geral portuguesa, ao longo dos séculos - como o foi no Norte, do seu ponto de vista -, não fosse um caso fortuito que mudou o rumo da história do Brasil: a descoberta das minas de ouro. Eis como descreve ele a vitória do paulista sobre o nortista, que conduzirá, ao longo do tempo, à constituição do Brasil como nação autônoma: "Na riqueza do ouro encontrou a população de S. Paulo uma força predominante, com que impôs a sua supremacia - como homogeneidade, como coesão, como originalidade e autonomia nacional - às províncias do Norte, cuja existência era artificial, na população toda estrangeira, quer nos brancos portugueses, quer nos negros africanos; artificial no regime do trabalho e natureza da cultura: cuja vida, enfim, era a de uma faz̧enda ultramarina de Portugal, amanhada e cultivada pelo gênio dos estadistas, e não a de uma nação nova existindo independente e autônoma, por virtude de uma população fixada e naturalizada no solo sobre que vivia".

A nação brasileira, portanto, vai sobreviver graças à preservação, nos paulistas, do gênio descobridor português, fixado na terra e erguido a um lugar de poder pela descoberta fortuita da minas, no século XVIII. 
E por que São Paulo não se corrompeu, não integrou a corrente descendente em que Portugal mergulhou desde a segunda metade do século XVI? Perguntar isso é o mesmo que perguntar por que Martins pôde dizer que "o Brasil se salvou apesar dos Braganças reinarem em Portugal". ${ }^{10}$

Esse ponto não é devidamente esclarecido no texto. Em algumas passagens parece sugerir Martins que foi o caráter aventureiro de que logo se revestiu a vida paulista, com as entradas e bandeiras, que respondeu pela manutenção do gênio explorador português nessa parte do país, enquanto as demais o perdiam pela vida ociosa, apoiada na escravidão e dissolvida pelo luxo excessivo.

De qualquer forma, o que importa notar é que, segundo Martins, "o espírito aventureiro dos paulistas foi a primeira alma da nação brasileira; e São Paulo, esse foco de lendas e tradições maravilhosas, o coração do país". "Graças a esse espírito aventureiro, haveria em São Paulo um germe de nação já no final do século XVI. Assim, para Martins, o Brasil se forma como nação forte, na mesma época em que Portugal mergulha na mais profunda decadência. E se forma como tal por obra dos paulistas e por obra do acaso, que foi a descoberta das minas.

Esse é o primeiro eixo, e o central, do livro sobre o Brasil: a narrativa da adaptação de uma das facetas do gênio português a um novo espaço geográfico, em que pôde sobreviver e desenvolver-se, preservado da decadência metropolitana. É por essa narrativa que O Brasil e as colônias portuguesas se integra no quadro mais amplo, de que também fazem parte a História de Portugal e a História da Civilização Ibérica.

Um segundo eixo de articulação do texto de Martins é o que se dedica às circunstâncias particulares dessa adaptação, e que consiste na defesa da escravidão do negro e da guerra ao indígena. Dele decorre, em primeiro lugar, um sistemático combate à atividade jesuítica. Dele decorre também a parte menos legível do seu texto, que é a exposição reiterada de sua concepção da superioridade racial dos arianos e o esforço bru- 
tal para demonstrar, com base na literatura racista da época, o caráter pouco humano, ou inferiormente humano, da raça negra.

Quanto ao argumento racista, há pouco a dizer, mas a ele voltarei em breve. Já a concepção de que o índio representa um obstáculo à expansão ariana, que deveria ser assimilado ou simplesmente destruído, merece mais atenção, porque o combate ao jesuíta provém da concepção de que uma sociedade indígena "cretinizada" pelos padres representaria uma aberração histórica e a eliminação de qualquer possibilidade de o Brasil vir a ser uma nação civilizada.

Isso, claro, porque, para Martins, civilizada significava, essencialmente, européia. De modo que o libelo antijesuítico que perpassa toda a História de Portugal recebe aqui cor local e mais contundência, aliado à certeza de que a afirmação da igualdade essencial das raças humanas era apenas uma quimera do pensamento cristão, nada científica.

Já no que diz respeito ao negro, o ponto interessante a notar é que, apesar das hoje revoltantes páginas racistas, há um momento no livro de Martins em que fala não o cientista social, não o ardoroso defensor das teorias da supremacia da raça branca, mas o artista que nos acostumáramos a admirar em outros volumes. Trata-se da descrição do quilombo de Palmares, página memorável em que, esquecendo-se por instantes de todos os preconceitos, o escritor celebra a cidade negra.

Afirmando que em Palmares temos o mais belo e heróico exemplo do protesto e da revolta dos escravos, chama-lhe república, e diz que ali se tinha um agrupamento humano que bem merecia o nome de nação, e que se comparava, pela forma de organização, à Roma primitiva, e, pelo destino, à grandeza de Tróia. ${ }^{12}$ Essa contradição entre os pressupostos teóricos e as necessidades da composição artística, tão fortemente assinalável nos vários livros de Oliveira Martins, embora extremamente interessante, não poderá ser investigada aqui. Basta, no momento, registrar que o darwinismo social adotado pelo historiador faz com que, tirante essa página, todo o seu livro possa ser lido como uma decidida defesa da escravidão do negro e do extermínio das populações indígenas como 
etapas necessárias à construção de uma sociedade civilizada, européia, no Novo Mundo.

Um último ponto a ressaltar, na visão martiniana do Brasil, é a sua preocupação constante com o futuro da grande obra portuguesa. De duas formas essa preocupação se manifesta, no que diz respeito ao Brasil seu contemporâneo. Por um lado, Martins se preocupa com a falta de um passo necessário e decisivo para a plena constituição da nação brasileira: a diversificação da economia, que ele considera ainda de moldes coloniais, fundada na monocultura, primeiro do açúcar e então do café. Por outro lado, assusta-o a possibilidade de fragmentação do vasto território, devido a uma política de imigração que ele considerava inadequada. Como o Império incentivasse a imigração dos países nórdicos, defende o incentivo à imigração de italianos e espanhóis, como forma de promover a homogeneização da população, reforçando o predomínio do caráter latino na nacionalidade brasileira. Mas esse é um aspecto menor da sua visada, e já não diz respeito à história pregressa do Brasil, mas ao seu futuro e permanência enquanto unidade nacional.

Tendo assim traçado o que julgo serem as teses fundamentais de Oliveira Martins, é o caso, agora, de passar à segunda parte do trabalho, isto é: de tentar observar algumas de suas repercussões e modalizações em textos brasileiros.

Logo num primeiro momento, o diálogo com a obra de Martins sobre o Brasil encontra uma expressão muito eloqüente na obra fragmentária de Eduardo Prado. Amigo pessoal de vários integrantes da Geração de 70, Prado teve longa e íntima convivência com Martins e com Eça de Queirós. Monarquista, católico, patriota exaltado, Eduardo Prado não podia aceitar inteiramente a condenação martiniana da Companhia de Jesus e da sua obra catequista. Como não podia também deixar de valorizar, na obra do amigo português, a exaltação dos paulistas como a base da nacionalidade brasileira e a melhor expressão do gênio português transplantado para a América. Assim, se dedicou boa parte de seu tempo a estudos sobre os jesuítas, no intuito de mostrar, contra a opinião de 
Martins, a importância da obra catequista para a definição da nacionalidade brasileira, também tratou de corrigir a opinião daquele escritor sobre a forma e o sentido da mestiçagem entre o europeu e o índio.

Entre os vários trabalhos de Eduardo Prado, há um texto que nos interessa especialmente. Trata-se de uma conferência pronunciada em 1896, intitulada "O Catolicismo, a Companhia de Jesus e a Colonização do Novo Mundo". "Vemos aí retomadas algumas teses de Martins: o heroísmo tingido de uma ponta de loucura, que levou Portugal a realizar uma tarefa desmedida para o seu tamanho e capacidade populacional, e a reafirmação do papel central de São Paulo para a constituição do Brasil. Mas o que é novo é a defesa intransigente da Companhia de Jesus, responsável, entre outras grandes obras, por duas que Prado destaca e que crê relacionadas: a fundação de São Paulo e a domesticação do índio, que permitiu a mestiçagem cabocla, por ele considerada a origem da força específica que o próprio Martins descobrira na população paulista.

A tese mais interessante desse trabalho de Eduardo Prado é, porém, aquela que explica o que ficara mais ou menos inexplicado no texto de Oliveira Martins: por que em São Paulo, e apenas em São Paulo, pôde-se preservar o antigo heroísmo português, desaparecido na pátria-mãe depois da morte nacional simbolizada no desastre de Alcácer-Quibir.

A explicação de Eduardo Prado vai em duas direções: de um lado, temos o elogio da mestiçagem, em que o branco entra com o cérebro mais desenvolvido e o índio com "a agudeza da sensibilidade dos seus sentidos e a agilidade elástica dos seus músculos", formando assim um tipo, não inferior, mas superior e mais adaptado à empresa de desbravamento que foi a dos paulistas. ${ }^{14}$ De outro - e este ponto é muito importante -, temos a afirmação de que o isolamento de São Paulo em relação à costa teve papel decisivo na formação da nova raça. Isso porque a localização geográfica teria permitido simultaneamente que a sua população se mantivesse fora do "contato imediato com a gente do mar, forasteiros e aventureiros", cujo convívio era "corruptor e fatal", e que ali predominasse o europeu, pois o clima não lhe era tão hostil quanto ao nível do 
mar. Foi essa convergência de circunstâncias que, segundo Eduardo Prado, permitiu que no Planalto se formasse o tipo adequado à colonização dos trópicos: o cabloco paulista. São Paulo foi, assim, uma "oficina de homens", e o berço da que poderia ser chamada a raça brasileira.

A tese de que o isolamento de São Paulo foi responsável pela manutenção de qualidades que se perderam ou nunca chegaram a existir no litoral fará fortuna crítica, pois permite separar os portugueses do Brasil (devidamente mestiçados com o índio, é verdade), dos decadentes portugueses dos períodos filipino e bragantino, tão estigmatizados por Oliveira Martins e tão hostilizados pela propaganda republicana.

Compõe-se, dessa forma, um quadro muito interessante, que persistirá pelo menos até os anos 30 do nosso século: uma singular mistura de antilusitanismo e de elogio das virtudes portuguesas dos fundadores e propulsores do progresso brasileiro. Ainda em Eduardo Prado não há antilusitanismo, mas já nas fileiras republicanas ele será o tom dominante, e Oliveira Martins será muito freqüentemente a referência mais forte do discurso antilusitano e antibragantino.

O desolado quadro da decadência portuguesa traçado por Martins, conjugado à tese de Eduardo Prado de que o isolamento foi a forma pela qual se mantiveram, em alguma população brasileira, as boas qualidades étnicas do período heróico, vai reaparecer num dos textos mais importantes da literatura brasileira do começo deste século: Os Sertões, de Euclides da Cunha. Mas já aqui o isolamento das populações interioranas não terá sempre um valor positivo, pois tanto servirá para preservar as boas qualidades renascentistas, quanto para cristalizar os vícios da decadência, transplantados para o Brasil ao longo dos séculos coloniais.

Assim, na mesma linha de Martins e Eduardo Prado, na tipologia do homem brasileiro distingue Euclides o habitante do litoral e o paulista, nome que designa "os filhos do Rio de Janeiro, Minas, São Paulo e regiões do sul", que resultaram da melhor aclimatação dos primeiros portugueses e da absorção, por eles, das populações indígenas. Com o mesmo entusiasmo de seus predecessores, vai chamar a esses paulistas 
"cruzados das conquistas sertanejas", definindo-os racialmente como os "mamalucos audazes". Os paulistas de Euclides, como os de Martins e Eduardo Prado, são essencialmente os habitantes do planalto. $\mathrm{O}$ isolamento geográfico era simultaneamente uma proteção militar - "a disposição orográfica (diz Euclides) libertava-o da preocupação de defender o litoral, onde aproava a cobiça do estrangeiro" - e moral, contra a degeneração operada pelo clima litorâneo, que "delia num clima enervante" "a força viva restante do temperamento dos que vinham de romper o mar imoto".

Mas se o isolamento fora benéfico na construção da raça paulista, tivera efeito diverso sobre as populações sertanejas do Norte. Lá, a falta de contato com outros agrupamentos humanos produzira monstruosidades, entre as quais a religiosidade mestiça, cujos "fatores históricos" o autor vê como um "caso notável de atavismo, na história". Segundo Euclides, que se apóia expressamente em Oliveira Martins para traçar o quadro da decadência portuguesa e dos fatores que a explicariam, "o povoamento do Brasil fez-se, intenso, com D. João III, precisamente no fastígio de completo desequilíbrio moral, quando 'todos os terrores da Idade Média tinham cristalizado no catolicismo peninsular" ". ${ }^{15}$ Por se manterem relativamente isoladas, as populações sertanejas apresentariam, ainda nos tempos modernos, cristalizados, os vários momentos da loucura e degenerescência coletiva que foi a história de Portugal desde o reinado faustoso e já decadente de D. Manuel: "Esta justaposição histórica - diz Euclides - calca-se sobre três séculos. Mas é exata, completa, sem dobras. Imóvel o tempo sobre a rústica sociedade sertaneja, despeada do movimento geral da evolução humana, ela respira ainda na mesma atmosfera moral dos iluminados que encalçavam, doidos, o Miguelinho ou o Bandarra. Nem lhe falta, para completar o símile, o misticismo político do Sebastianismo. Extinto em Portugal, ele persiste todo, hoje, de modo singularmente impressionador, nos sertões do norte".

Portanto, enquanto os isolados do Sul cristalizaram o que de melhor havia na índole do português descobridor, guardaram os do Norte 
apenas a herança negativa, os vícios da metrópole decadente. E se, no primeiro caso, o contato intenso com outros povos e culturas poderia ser nocivo à manutenção do caráter heróico dos mamelucos, já no segundo poderia ter amenizado talvez as taras herdadas dos portugueses decadentes que continuaram a colonização do Brasil.

A tese de que o isolamento preservou no Brasil os traços heróicos do caráter português e permitiu preservar da decadência geral um significativo segmento da população da colônia terá uma larga fortuna e muitas modalizações, que entretanto pouco lhe acrescentam em termos de novidade. Muito mais importante do que os desenvolvimentos das idéias de Eduardo Prado ou de Euclides, do ponto de vista da história da influência de Oliveira Martins no pensamento brasileiro do começo do século $\mathrm{XX}$, é o que veio num volume publicado quase ao mesmo tempo que $O s$ Sertões, mas que, não obstante a qualidade de sua reflexão, ficou quase esquecido ao longo de oito décadas. Trata-se do ensaio A América Latina - Males de Origem, de autoria de Manoel Bomfim.

Manoel Bomfim talvez seja ainda hoje mais conhecido como o co-autor de Através do Brasil, livro de leitura escolar escrito de parceria com Olavo Bilac. Sua obra principal, porém, é o referido ensaio, que foi publicado em 1905, em Paris, e republicado em 1938.

Recentemente, em 1993, o livro foi relançado pela Topbooks, com um prefácio acalorado de Darcy Ribeiro, no qual o autor se mostra revoltado por o livro não ter tido a repercussão que merecia e chama a Manoel Bomfim "o fundador da antropologia do Brasil e dos brasileiros". ${ }^{16}$

Nesse trabalho, Bomfim desenvolve a tese de que o mal de origem da América Latina é o parasitismo das metrópoles, perpetuado, depois, no parasitismo das classes dominantes. Como avalia e resume Darcy Ribeiro, "Manuel Bomfim surgia com um livro sábio e profundo [...] em que demonstra cabalmente, dizendo-o com todas as letras [...] que nossos males não vêm do povo. São, isto sim, produto da mediocridade do projeto das classes dominantes que aqui organizaram nossas socieda- 
des em proveito próprio, com o maior descaso pelo povo trabalhador, visto como uma mera fonte de energia produtiva".

Pretendendo dar do Brasil uma visão real, e não coada pelos preconceitos da antropologia e das teorias políticas européias, Bomfim produz um discurso profundamente nacionalista e, por isso mesmo, nos termos daquele momento, profundamente antilusitano.

$\mathrm{E}$ aqui aparece uma questão muito interessante. Como organiza Bomfim o seu discurso antilusitano? Apoiando-se inteira e extensamente nas obras de Oliveira Martins. Dizendo assim, é difícil fazer idéia real do aproveitamento de Martins por Bomfim. É preciso olhar para as páginas do volume, para poder bem avaliar a interação dos textos: praticamente todas as inúmeras citações destacadas do corpo do discurso são do historiador português. Ś́lvio Romero, numa crítica virulenta ao livro, teve a pachorra de contar as linhas escritas por Bomfim e as que foram transcritas de Martins. Na terceira parte do livro, chegou a estes números: das 2.276 linhas, 1.114 são do historiador português. "Mais da metade!", exclama Sílvio, que concentra então suas baterias em Oliveira Martins, chamando aos seus dois livros principais, História de Portugal e História da civilização ibérica, "dois panfletos histórico-políticos [...], livros perniciosíssimos, causadores de males incalculáveis entre diletantes". ${ }^{17}$

Comentando a crítica de Romero, Darcy Ribeiro escreveu: "Pouco depois de publicada, ela foi objeto de todo um livro de contestação do genioso Sílvio Romero. Nesta polêmica, Sílvio desanca Manoel Bomfim procurando demonstrar que ele é um completo idiota. Idiota era Sílvio, coitado. Tão diligente no esforço de compreender o Brasil, mas tão habitado pelos pensadores europeus em moda, que só sabia papagaiá-los”. É curiosa esta crítica, porque silencia sobre o ponto central dos reparos de Romero, segundo o qual Bomfim papagaiava Oliveira Martins...

Ora, sem qualquer juízo de valor, é justamente esse aproveitamento tão intenso dos livros de Martins o que mais interessa aqui. É verdade que Bomfim discorda profundamente de Martins em alguns 
aspectos fundamentais da sua interpretação do Brasil. Principalmente das teorias racistas sobre a inferioridade congênita do negro. Mas a visão martiniana do que foi a história portuguesa e de quais os males principais da organização da sociedade da metrópole que se teriam transmitido ao Brasil é o verdadeiro eixo desse livro excepcional.

O diagnóstico dos males de origem das sociedades latino-americanas se processa segundo duas linhas argumentativas. Em primeiro lugar, vem a tese do parasitismo das nações ibéricas. Em segundo, a de que os males da sociedade brasileira se explicam em grande parte pelo que chamou de os remanescentes do parasitismo metropolitano, cujo lugar de expressão é o Estado brasileiro, divorciado das necessidades populares, e cujo traço político é o conservadorismo das elites.

Para o desenvolvimento dos dois argumentos, a obra de Oliveira Martins fornece a base ideológica, quando não o próprio vocabulário. Mesmo a idéia do parasitismo ocorre repetidamente em Martins, em passagens que são reproduzidas e, às vezes, repetidas em pontos diferentes do livro. Como esta: "Enxame de parasitas imundos, desembargadores e repentistas, peraltas e sécias, frades e freiras, monsenhores e castrados... [...] Portugal quase que se tornara um comunismo monástico, em que as classes privilegiadas, fruindo todos os rendimentos, distribuíam comedorias à nação sob a forma de empregos e outras". Essa passagem, por exemplo, comparece duas vezes no livro de Bomfim: primeiro para comprovar o caráter parasitário interno à própria sociedade metropolitana; e depois, quando trata do Estado brasileiro, vemo-la novamente, agora como fragmento de uma colagem com um trecho de $O$ Brasil e as colónias portuguesas, de modo a demonstrar a transferência da praga metropolitana para o Brasil, com a vinda da corte de D. João VI. O trecho com que vem montada é bastante eloqüente: "Uma nuvem de gafanhotos, que desde o século XVII devorava tudo em Portugal, e ia pousar agora no Brasil, para, em casa, o digerir mais à vontade...". ${ }^{18}$

Demonstrado, dessa forma, o caráter parasitário das classes dominantes portuguesas com as citações de Martins, e assim apoiada a tese 
numa autoridade insuspeita, por portuguesa, Bomfim desenvolve o seu segundo argumento: o de que boa parte dos males nacionais é resultante dos resíduos ou remanescentes da metrópole. Por esses termos, Bomfim entende os segmentos da sociedade que representam "diretamente os interesses parasitas", que constituem "uma parte da metrópole plantada na colônia". São eles que reprimiram os movimentos de emancipação real do país, pensa Bomfim, e foram eles que, conservadoramente, mantendo os privilégios parasitários, arranjaram a Independência, em acordos sem a participação popular. Na síntese do seu diagnóstico sobre os males das sociedades latino-americanas, escreve Bomfim: "As classes dirigentes, herdeiras diretas, continuadoras indefectíveis das tradições governamentais, políticas e sociais do Estado-metrópole, parecem incapazes de vencer o peso dessa herança; e tudo o que o parasitismo peninsular incrustou no caráter e na inteligência dos governantes de então, aqui se encontra nas novas classes dirigentes; qualquer que seja o indivíduo, qualquer que seja o seu ponto de partida e o seu programa, o traço ibérico lá está o conservantismo, o formalismo, a ausência de vida, o tradicionalismo, a sensatez conselheiral, um horror instintivo ao progresso, ao novo, ao desconhecido, horror bem instintivo e inconsciente, pois que é herdado". Os resultados dessa herança eram muito semelhantes ao quadro traçado por Oliveira Martins, no Portugal finissecular. Apenas se atualizavam os termos: "O resultado desse passado recalcitrante é esta sociedade que aí está: pobre, esgotada, ignara, embrutecida, apática, sem noção do próprio valor, esperando dos céus remédio à sua miséria, pedindo fortuna ao azar - loterias, jogo de bichos, romarias, 'ex-votos'; analfabetismo, incompetência, falta de preparo para a vida, superstições e crendices, teias de aranha sobre inteligências abandonadas...". 19

Curiosamente, sucede com o texto de Bomfim o mesmo que com o de Martins: hoje já o estilo não é o nosso, nem as teses básicas parecem sustentáveis, nem os dados em que se apóiam muito confiáveis. Entretanto, muitos leitores brasileiros de hoje saem da leitura com uma forte impressão de realidade e adequação, e, pelo menos quanto a mim, pare- 
cem muito exatas estas palavras de Luís Paulino Bomfim, de 1993: “O grande drama do continente americano é que, nos dias de hoje, $A$ América Latina de Manoel Bomfim, que deveria ser como um videotape em preto e branco do passado, se apresenta como uma reportagem em cores - e ao vivo - do presente". ${ }^{20}$

Como se explica esse fenômeno? Tratar-se-ia de uma profunda intuição histórica, que se impõe até hoje apesar do instrumental analítico? Ou apenas de uma alta coerência estética na formação dos argumentos e na sua exposição literária? A resposta a essas questões constitui um desafio para a compreensão do sentido e do alcance de um certo discurso que foi o de Martins e também o de Bomfim. Mas o lugar de responder a esse desafio não é, decerto, este.

Aqui, nos limites desta primeira aproximação, o importante é ressaltar que, por meio da incorporação das teses, do estilo acusatório e admoestativo e da visada central de Oliveira Martins sobre a decadência e o parasitismo estruturante das sociedades peninsulares, Bomfim vai compor um texto de alto poder de persuasão e grande consistência literária. Corrigindo o pendor racista dos trabalhos de Martins, abria ele também as portas a uma nova compreensão do sentido da mistura racial no Brasil, e foi realmente uma pena que o seu livro não criasse escola, nem fosse o início de uma nova corrente de pensamento brasileiro, como justamente lamenta Darcy Ribeiro.

Nos anos subseqüentes, temos ainda dois momentos fortes em que Martins desempenha um papel importante no pensamento brasileiro, antes que sua presença se vá fazendo sentir cada vez menos e sua influência seja suplantada, nos meios eruditos, por outras interpretações da história de Portugal - principalmente a de António Sérgio e, depois, por efeito de sua estada prolongada entre nós, a de Jaime Cortesão.

O primeiro é constituído, na década de 1920, por dois livros de Paulo Prado - Paulística (1925) e Retrato do Brasil (1928) -, cuja reflexão etnológica e histórica se articulará sobre a oposição entre os brasileiros do litoral e os do planalto, conjugada a uma especulação sobre os vários 
tipos de mestiçagem e seus efeitos culturais. Mas não tratarei desses livros aqui, por dois motivos. Primeiro, porque a apresentação do que neles há de martiniano já foi feita, num trabalho acadêmico recentemente publicado em livro. ${ }^{21}$ Segundo, porque Paulo Prado parece apenas desenvolver, no tocante a Oliveira Martins, os mesmos tópicos que já identificamos no comentário dos textos de Eduardo Prado e de Euclides da Cunha.

Mais importante, porque ainda por estudar, é a presença do pensamento de Oliveira Martins na obra de Gilberto Freyre. A consulta ao índice onomástico de alguns dos seus livros indicará a importância de Martins para o seu pensamento. Mas o lugar do historiador português na obra de Freyre é maior do que o ocupado pelo conjunto das várias citações, porque, mais do que de referência, é um lugar de método.

Sei que a afirmativa parecerá estranha, sendo tão díspar a forma de organização textual. Mas penso que a forma de conceber a história tem em ambos notáveis semelhanças. No prefácio da primeira edição de Casa-Grande \& Senzala, lemos estas palavras: "A história social da casagrande é a história ínitima de quase todo brasileiro: de sua vida doméstica, conjugal, sob o patriarcalismo escravocrata e polígamo [...] O estudo da história íntima de um povo tem alguma cousa de instrospecção proustiana". E mais, adiante:

\footnotetext{
No estudo da sua bistória intima despreza-se tudo o que a bistória política e militar nos oferece de empolgante por uma quase rotina de vida: mas dentro dessa rotina é que melhor se sente o caráter de um povo. Estudando a vida doméstica dos antepassados sentimo-nos aos poucos nos completar: é outro meio de procurar-se o "tempo perdido". Outro meio de nos sentirmos nos outros - nos que viveram antes de nós; e em cuja vida se antecipou a nossa. É um passado que se estuda tocando em nervos; um passado que emenda com a vida de cada um; uma aventura de sensibilidade, não apenas um esforço de pesquisa pelos arquivos. ${ }^{22}$
}

Compare-se essa passagem com o que escrevia cinqüenta anos antes Oliveira Martins, na Advertência da sua História de Portugal: 
Nada disso, porém, é ainda realmente a bistória, embora todas essas condiçoes sejam indispensáveis para a sua compreensão. O intimo e essencial consiste no sistema das instituições e nos sistemas das idéias coletivas, que são para a sociedade como os órgãos e os sentimentos são para o indivíduo, consistindo, por outro lado, no desenho real dos costumes e dos caracteres, na pintura animada dos lugares e acessórios que forma o cenário do teatro histórico. ${ }^{23}$

Ao que, na resposta aos críticos do seu livro, acrescenta ainda:

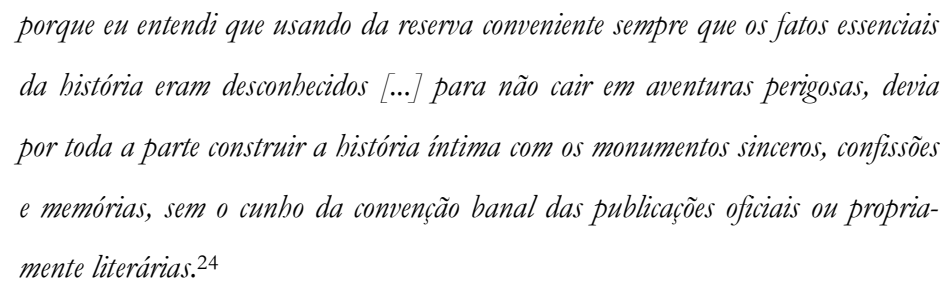

Foi a especificidade do ponto de vista martiniano, ao empenharse na reconstrução da história íntima da nação, que Antonio José Saraiva acabou por reconhecer como a grande conquista de Martins. E é curioso que para descrever essa especificidade tenha utilizado a mesma expressão utilizada por Freyre para descrever o próprio texto: uma "história introspectiva". E da mesma forma que, na reavaliação de Eduardo Lourenço, a História de Martins constitui o "imaginário coletivo" da modernidade portuguesa, cada vez mais nos apercebemos que a mesma função tem a obra de Freyre, no Brasil de hoje.

Essa homologia de função era algo que o próprio Freyre parecia entrever e desejar. Pelo menos, é o que se depreende da leitura de um romance seu, pouco conhecido. Trata-se de O outro amor do Dr. Paulo, que é, nas suas próprias palavras, uma "seminovela", um texto ficcional de intenção histórica.

A personagem central é um brasileiro chamado Paulo, que passa longo tempo na Europa, onde convive, no final do século, com o Barão de Rio Branco, Eduardo Prado e Eça de Queirós, entre outros. As passagens que interessam aqui são duas. Numa delas, Paulo presencia uma 
cena em que outro brasileiro diz a Eça que o Brasil precisava ter um Eça de Queirós. Eça então responde: "Não, não precisa. [...] Precisa de um Oliveira Martins, historiador, sociólogo, pensador, ensaísta em profundidade. [...] Cada vez admiro mais Machado de Assis. E Portugal nada seria sem Oliveira Martins". 25

No final do romance, a mesma afirmação é atribuída a Eça. Mas numa situação que revela com muito vigor a homologia entre Freyre e Martins. No texto, a frase aparece justamente depois de o narrador fazer uma digressão sobre o sistema patriarcal no Brasil, a que, justamente, Freyre consagrara suas obras principais. No romance, o tempo histórico é anterior, e assim surgem como profecias de si mesmo estas frases do narrador da seminovela:

\footnotetext{
Evidentemente esse sistema patriarcal de família - o brasileiro projetado sobre Portugal - com afinidades com o grego, não tivera ainda o seu analista. Eça de Queirós tinha alguma razão quando dissera uma vez, no apartamento de Eduardo Prado, em resposta ao reparo de um brasileiro de que o Brasil precisava de ter um Eça de Queirós: "O Brasil já tem um mestre nesse gênero de literatura que é Machado de Assis. O Brasil precisa é de grandes pensadores e historiadores que o analisem e interpretem. Precisa, tanto quanto Portugal precisou, de um Antero, de um Oliveira Martins, de um Ramalho Ortigão. Precisa muito de um Oliveira Martins". Mais ou menos o que dissera quando visitado por Paulo e seu grupo. ${ }^{26}$
}

Assim, embora não seja o caso de desenvolver a reflexão sobre que pontos, de fato, Freyre incorporou da obra ou das idéias de Martins, registre-se esse seu testemunho, como mais uma prova de que, pela interpretação global do que foi a história da nação portuguesa - interpretação essa que a muitos brasileiros tem parecido a mais adequada e convincente -, parece fora de dúvida que a obra de Oliveira Martins vem organizando, em vários níveis, ao longo de mais de cem anos e quase até o presente, nossa visão do que foi e do que é Portugal e do que foi ou é o Brasil enquanto produto da pequena nação ibérica. 
Neste texto, que é apenas um balanço parcial dos resultados de um trabalho ainda inconcluso, contento-me em apresentar este mapeamento sumário de um território pouco conhecido, mas que, pela importância do que pode revelar a respeito da história do pensamento brasileiro, sem dúvida merece e precisa ser melhor explorado.

\section{Notas}

* Com pequenas atualizações, este texto reproduz uma conferência lida no Departamento de História da Universidade de Lisboa, em 13/04/2000, que, por sua vez retomava e ampliava um artigo publicado anteriormente na revista Voz Lusíada, de São Paulo.

1 Pires, A. Machado. A ideia de decadência na Geração de 70. Foi publicada recentemente uma segunda edição desse livro fundamental: Lisboa, Vega, 1992.

2 Ver, a propósito da Biblioteca, o excelente trabalho de AbdoolKarim Vakil: Leituras de Oliveira Martins: história, ciências sociais e modernidade económica. Comunicação apresentada ao "Congresso Internacional Oliveira Martins: Listeratura, história, política". Coimbra, abril de 1995.

3 A. Sérgio. "Oliveira Martins: impressões sobre o significado político da sua obra". In: Martins, J. P. Oliveira. Dispersos. Lisboa: Biblioteca Nacional, 1923, p. xxxviii.

4 Apud Martins, Wilson. História da inteligência brasileira, vol. V. São Paulo: Cultrix/Edusp, 1977-78, p. 560.

5 A. J. Saraiva. A tertúlia ocidental. Lisboa: Gradiva, 1990.

6 A. Sérgio, op. cit., p. xxvii.

7 Portugal nos Mares. Lisboa: Ulmeiro, 1984, p. 10.

8 Ver, a propósito do conceito de nação e nacionalidade em Oliveira Martins, o meu texto "No centenário de morte de Oliveira Martins", de onde retomei, com algumas modificações, os parágrafos anteriores. In Martins, J. P. de Oliveira \& Queirós, J. M. Eça de. Correspondência. Campinas: Editora da Unicamp. 1995.

9 O Brasil e as colónias portuguesas. Lisboa: Guimarães e Cia. Editores, 1953, p. 2.

10 O Brasil..., cit., p. 36.

11 O Brasil..., pp. 80-81. 
12 Manoel Bomfim, no livro A América Latina - Males de origem, que comentarei a seguir, notou bem essa contradição do texto martiniano.

13 In Collectaneas, vol. IV. São Paulo: Escola Typographica Salesiana, 1906.

14 Prado, E., Op. cit., p. 85.

15 Todas as citações são do texto de Os Sertões. Euclides da Cunha. Obra Completa, vol.

2. Rio de Janeiro: Editora Aguilar, 1995, pp. 155, 197 e 198.

16 In Manoel Bomfim. A América Latina - Males de Origem. Rio de Janeiro: Topbooks, 1993, p. 18.

17 Sylvio Romero. A América Latina. (Analyse do livro de igual título do Dr. M. Bomfim). Porto: Livraria Chardron, 1906, p. 50.

18 Bomfim, op. cit., p. 111 e p.227.

19 Bomfim, op. cit., pp. 327-8.

20 "Pequena biografia de Manoel Bomfim". In Bomfim, Manoel, op. cit., p. 358.

21 Berriel, Carlos. Tietê, Tejo, Sena: a obra de Paulo Prado. Campinas: Papirus, 2000.

22 "Prefácio à primeira edição". In Freyre, Gilberto. Casa-Grande e Senzala. SãoPaulo: Círculo do Livro, 1986, p. 26.

23 Martins, Oliveira. História de Portugal. Lisboa: Guimarães Editores, 1991, p. 8.

24 A História de Portugal - Os críticos da $1^{a}$ edição. Repr. in Albuquerque, Isabel de Faria e (ed.). História de Portugal de J. P. Oliveira Martins. Lisboa: Imprensa Nacional-Casa da Moeda, 1988. O trecho citado está na p. 218.

25 Freyre, Gilberto. O outro amor do Dr. Paulo. Rio de Janeiro: Livraria José Olympio Editora, 1977, p. 91.

26 Freyre, G, ibid. p. 193. 